\title{
Getting the food out: A content analysis of the online communication of Seattle food banks during the initial response to COVID-19
}

\author{
Audrey L. Immel, ${ }^{a}$ Yona Sipos, ${ }^{\mathrm{b}}$ Amber S. Khan, ${ }^{\mathrm{c}}$ \\ and Nicole A. Errett d* \\ University of Washington
}

THE IMPACT OF COVID-19 ON FOOD SYSTEMS
COSPONSORED BY INFAS:

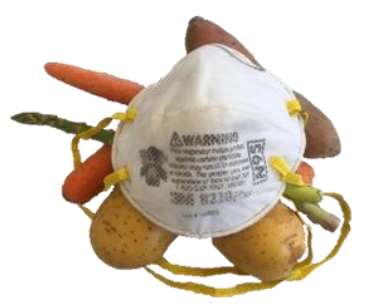

Inter-institutional

Network for

Food and

Agricultural

Sustainability

Submitted September 29, 2020 / Revised January 18 and June 29, 2021 / Accepted July 2, 2021 /

Published online September 14, 2021

Citation: Immel, A. L., Sipos, Y., Khan, A. S., \& Errett, N. A. (2021). Getting the food out: A

content analysis of the online communication of Seattle food banks during the initial response

to COVID-19. Journal of Agriculture, Food Systems, and Community Development, 10(4), 267-282.

https://doi.org/10.5304/jafscd.2021.104.009

Copyright (C) 2021 by the Authors. Published by the Lyson Center for Civic Agriculture and Food Systems. Open access under CC-BY license.

\begin{abstract}
The COVID-19 pandemic has threatened food availability, accessibility, and acceptability. Food banks are experiencing increased demand at the same time as operational challenges due to COVID-19. The objective of this study was to assess if and how food banks have utilized web and social media platforms to communicate dynamic information relevant to food security to a growing clientele amid a widespread emergency. We conducted a content analysis of web and social media communications made by 25 Seattle food banks in April and May 2020, which corresponded with the two full months of Washington Governor

a Audrey L. Immel, BS, University of Washington

b Yona Sipos, Ph.D., University of Washington

c Amber S. Khan, MPH, University of Washington

$\mathrm{d} *$ Corresponding author: Nicole A. Errett, Ph.D., MSPH,

University of Washington; 4225 Roosevelt Way NE, Suite 100; Seattle, WA 98105 USA, nerrett@,uw.edu
\end{abstract}

Inslee's initial stay-at-home order (March 25-May 31, 2020). We developed and applied a codebook to assess if communications contained information related to food availability, accessibility, and acceptability in the context of COVID-19, as well as other descriptive information, such as changes to food bank operations. Our findings show that food banks in Seattle communicated the most on web and social media platforms about food availability and accessibility, while they communicated less commonly about food acceptability. Past disasters have exposed the need to include food acceptability in disaster planning to ensure that emergency food can be equitably distributed and

\footnotetext{
Funding Disclosure

This research was supported by the University of Washington's Mary Gates Endowment for Students and in part by the UW NIEHS sponsored Biostatistics, Epidemiologic and Bioinformatic Training in Environmental Health (BEBTEH) Training Grant, Grant \#: NIEHS T32ES015459.
} 
consumed by diverse populations. Our results suggest that food banks may wish to periodically assess the main themes of their online communications and the reach of their different platforms during the COVID-19 pandemic as one strategy to facilitate community food security.

\section{Keywords}

COVID-19, Pandemic, Disaster, Food Banks, Food Security, Social Media, Emergency

Communication

\section{Introduction}

Food security is defined as occurring "when all people, at all times, have physical and economic access to sufficient, safe and nutritious food that meets their dietary needs and food preferences for an active and healthy life" (Food and Agriculture Organization of the United Nations [FAO], 1996). Food insecurity is a significant public health concern given its association with a number of poor health outcomes, including diabetes, hypertension, and depression (Gundersen \& Ziliak, 2015). The FAO identifies three commonly accepted dimensions of food security: food availability, accessibility, and acceptability (FAO, 2006) (Table 1).

The ongoing COVID-19 pandemic has dramatically increased food insecurity in the United States by threatening these three components of food security (Bauer, 2020; Naja \& Hamadeh,
2020; Niles, Bertmann, Morgan et al., 2020) (Table 1). Challenges to maintaining food security during the pandemic are multifold. Economic barriers like skyrocketing unemployment and lost wages have been compounded by physical barriers such as avoidance of grocery stores to reduce potential COVID-19 exposure (Kochhar, 2020; Niles, Bertmann, Morgan, et al., 2020). Moreover, we have seen an intensification of prepandemic racial and ethnic disparities in food insecurity, particularly for Black and Hispanic households (Wolfson \& Leung, 2020b).

Food banks have served as an important source of emergency food aid in the context of the pandemic. In this exploratory study, we assess the web and social media communications of food banks based in Seattle, Washington (WA) - the first U.S. city hit by the COVID-19 pandemicduring its initial lockdown period. We aimed to determine the presence and frequency of clientfocused messaging around the three core components of food security (food availability, acceptability, and accessibility) to identify opportunities for improvement in holistic communications in other contexts, subsequent pandemic phases, and future disasters and public health emergencies.

\section{Learning from Past Disasters}

While there has not been a pandemic of this scale in the past 100 years, more recent disasters (e.g.,

Table 1. The Three Components of Food Security (Food Availability, Accessibility, and Acceptability) with Examples of Disruptions Due to Past Disasters and the Ongoing COVID-19 Pandemic

\begin{tabular}{|c|c|c|c|}
\hline Component of food security & Food availability & Food accessibility & Food acceptability \\
\hline Definition & $\begin{array}{l}\text { Food is present throughout } \\
\text { production, distribution, and } \\
\text { exchange (FAO, 2006) }\end{array}$ & $\begin{array}{l}\text { Food is present, and the com- } \\
\text { munity can acquire it without } \\
\text { barriers (physical, economic, } \\
\text { etc.) (FAO, 2006) }\end{array}$ & $\begin{array}{l}\text { Food is safe, nutritious, and } \\
\text { meets cultural and religious } \\
\text { needs (FAO, 2006) }\end{array}$ \\
\hline $\begin{array}{l}\text { Example of disruption } \\
\text { from past disaster }\end{array}$ & $\begin{array}{l}\text { Multiple retailers did not have } \\
\text { WIC-authorized foods in stock } \\
\text { after Hurricane Sandy (Zeuli \& } \\
\text { Nijhuis, 2017) }\end{array}$ & $\begin{array}{l}\text { During Winter Storm Jonas, } \\
\text { obstructed roads prevented } \\
\text { people from accessing food } \\
\text { distributors (Chodur et al., } \\
2018 \text { ) }\end{array}$ & $\begin{array}{l}\text { FEMA nutrition aid to Puerto } \\
\text { Rico did not meet DGA } \\
\text { Nutrition Guidelines after } \\
\text { Hurricane Maria (Colón- } \\
\text { Ramos et al., 2019) }\end{array}$ \\
\hline $\begin{array}{l}\text { Example of disruption } \\
\text { from COVID-19 }\end{array}$ & $\begin{array}{l}\text { Reduced donations of fresh } \\
\text { produce to food banks (Conlin } \\
\text { et al., 2020) }\end{array}$ & $\begin{array}{l}\text { Clients are unwilling or unable } \\
\text { to come to the food bank due } \\
\text { to social distancing require- } \\
\text { ments (Niles, Bertmann, } \\
\text { Morgan, et al., 2020) }\end{array}$ & $\begin{array}{l}\text { Prepackaged, to-go food } \\
\text { boxes for COVID-19 limit } \\
\text { client choice of food items } \\
\text { (Sheil, 2020) }\end{array}$ \\
\hline
\end{tabular}


extreme weather events) have demonstrated potential impacts to food security across the three domains of food availability, accessibility, and acceptability. Table 1 defines each element of food security and provides an example of the disruption of each element from both prior disasters and the COVID-19 pandemic. For example, 2016 Winter Storm Jonas in Baltimore, Maryland, disrupted food access by obstructing roads, preventing people from using cars, bikes, and buses. The obstructed roads also led to an overall decrease in food availability by disrupting food distribution (Chodur et al., 2018). Past disasters and emergencies have especially exposed the challenge and lack of priority for providing culturally, medically, and nutritiously acceptable emergency food to vulnerable populations. For example, Hurricane Maria demonstrated the importance of considering food acceptability in emergency food programs. Responding to social media criticisms of the unhealthy federal food aid to Puerto Rico following that hurricane, Colón-Ramos et al. (2019) analyzed FEMA emergency food items that were distributed. Using the Dietary Guidelines for Americans (DGA) as a benchmark, Ramos found that $41 \%$ of FEMA food items fell into the 'snacks and sweets' category, and $46 \%$ were high in sodium, added sugars, or saturated fats (Colón-Ramos et al., 2019). Food aid to Puerto Rico did not meet DGA guidelines, leaving this already vulnerable population recovering from a devastating hurricane without proper nutrition. Following Hurricane Sandy in 2012, the Metropolitan Council on Jewish Poverty in New York City exposed the lack of Kosher and Halal foods in emergency food banks and pantries, which left many Jewish and Muslim families without emergency food options (Karoub, 2014). The Jewish nonprofit worked with New York lawmakers, eventually leading to a provision in the 2014 farm bill that required the federal government to supply labeled Kosher and Halal emergency foods to food banks (Senator Kirsten Gillibrand, 2016).

\section{Food Insecurity During the COVID-19 Pandemic}

Food insecurity is rising above prepandemic levels in the United States, particularly among households with young children, low-income communities, and communities of color (Bauer, 2020; Drewnowski et al., 2020; Niles, Bertmann, Morgan, et al., 2020; Wolfson \& Leung, 2020a). Researchers in Vermont administered a statewide survey and found a nearly one-third increase in food insecurity from the year before the COVID-19 outbreak to after March 8, 2020 (Niles, Bertmann, Belarmino, et al., 2020). In their sample of 3,219 respondents, those who experienced a job loss were three times more likely to be food insecure (Niles, Bertmann, Belarmino, et al., 2020). The Washington State Food Security Survey, which was administered from June 18 to July 31, 2020, found that $30 \%$ of 2,621 Washington respondents were food insecure. Fifty-nine percent of those who were food insecure had children (Drewnowski et al., 2020).

With the loss of income and increasing food prices, people with low food security are more likely to struggle to maintain the recommended two-week supply of food to avoid excess grocery store trips during the COVID-19 outbreak (Johansson, 2020; Wolfson \& Leung, 2020a). Sixtyfour percent of respondents in the Washington State Food Security Survey reported concern with increasing food prices, and 29\% reported that they could not afford to stockpile food (Drewnowski et al., 2020). These economic threats to food security are compounded by physical barriers to food due to COVID-19 precautions. Social distancing guidelines and stay-at-home orders target older adults and people with preexisting conditions due to their increased vulnerability to COVID-19 complications, posing challenges to these populations accessing food in person at stores and community meals (Naja \& Hamadeh, 2020; Wolfson, Leung, \& Kullgren, 2020). People with special diets have also been reported to have challenges meeting their dietary needs during COVID-19 (Niles, Bertmann, Morgan et al., 2020). Closures of public schools around the country in response to coronavirus have also led to food instability for the millions of households whose children qualify for free or reduced lunch, with disproportionate impacts for Black and Hispanic households, who are more likely to qualify for free or reduced lunch (Kinsey et al., 2020). Researchers estimate that more than a billion school meals were missed due to COVID19 as of May 1, 2020 (Kinsey et al., 2020). 
Figure 1. Timeline of COVID-19 in Washington from First Confirmed Case in the State to Entering Phase 2

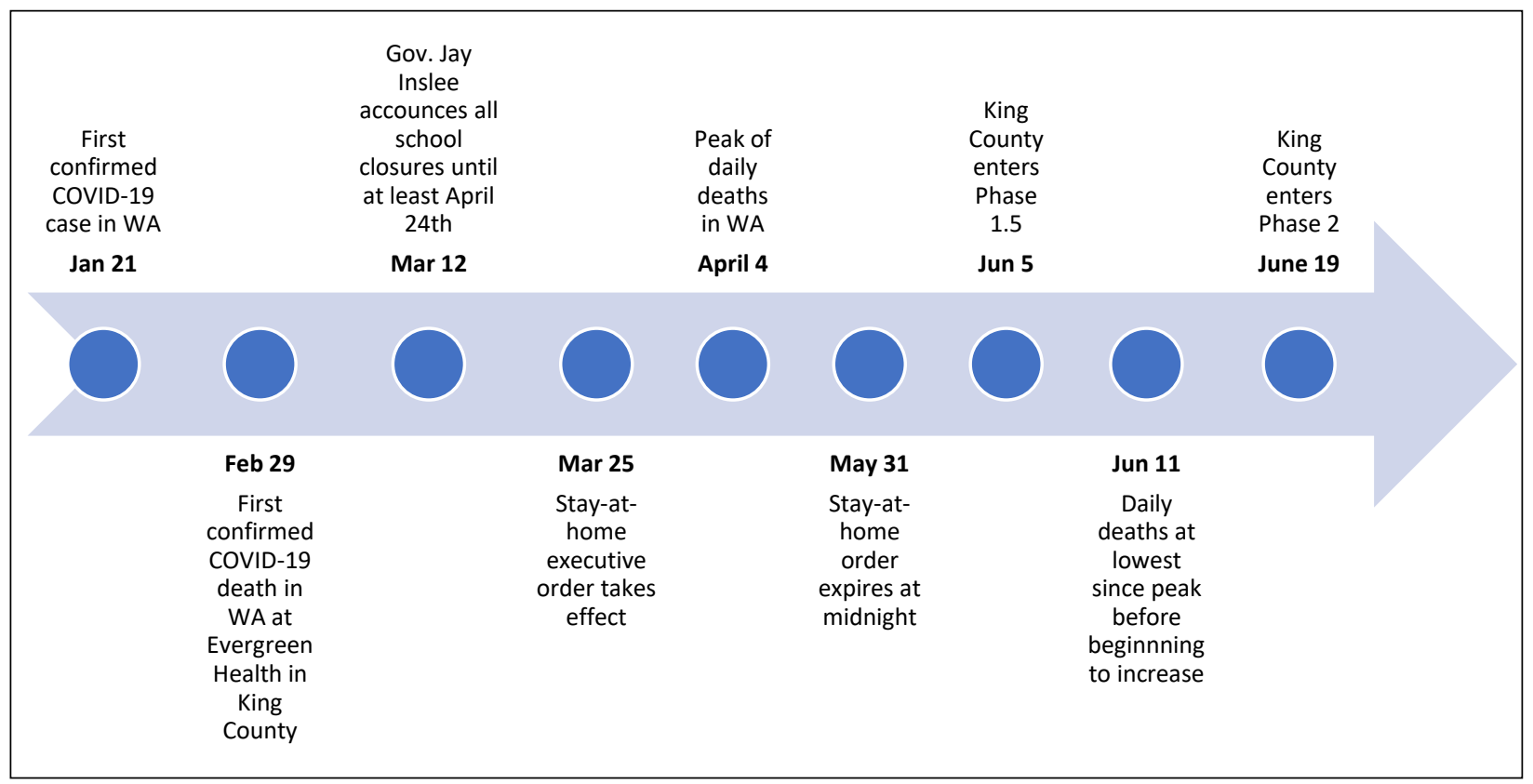

Source: IHME, 2020; King County, 2020a; King County, 2020b; KING 5 Staff, 2020.

\section{Seattle, WA: An Exploratory Analysis}

Washington quickly became an early epicenter of the COVID-19 pandemic after its first confirmed case on January 21, 2020 (Figure 1). On March 12, Governor Inslee announced all schools would be closed until at least April 24, and on March 23, he announced the stay-at-home executive order (McNerthney, 2020). The peak of daily deaths in Washington was on April 4, 2020 and by June 5, 2020, King County entered Phase 1.5 with limited reopenings of businesses (The Institute for Health Metrics and Evaluation [IHME], 2020; King County, 2020b). On June 11, 2020, Washington saw its lowest daily deaths since the peak, and King County entered Phase Two on June 19 with continued openings of businesses and small gatherings (IHME, 2020; King County, 2020b). Here, we describe the pre-COVID-19 food-insecurity landscape, as well as COVID-19's impacts on food insecurity.

In 2018, the rate of food insecurity in King County, Washington, of $9.5 \%$ was overall lower than the national average (11.5\%) (Feeding America, 2020). Yet in Seattle, food security is starkly divided along racial and neighborhood lines, exposing the immediate need to combat racism in both our food system and disaster response. A report from the Seattle City Council found that neighborhoods along the Duwamish waterway overlapped on all three factors of a Healthy Food Priority Area: low income, high percentage of unhealthy food retailers, and longer travel times to healthy food retailers (Bolt et al., 2019). Using the Seattle Healthy Food Survey, they also found that neighborhoods with more Black and Hispanic residents had lower healthy food availability scores. Among Seattle residents, the highest levels of food insecurity were found at an income level below $200 \%$ of the federal poverty line (FPL), which is the main eligibility criteria for the Supplemental Nutrition Assistance Program (SNAP), known as Basic Food in Washington State. However, food insecurity does not fully disappear until household income reaches $300 \%$ of the FPL, and $400 \%$ for families with young children and people of color, indicating a gap between those who are food insecure and those who are eligible to receive SNAP benefits (Bolt et al., 2019). In 2017, about 13,400 residents in Seattle had too much income to qualify for SNAP but experienced food insecurity, and in $2018,42 \%$ of food-insecure residents in 
King County were above the $200 \%$ FPL cutoff for SNAP (Feeding America, 2020b).

Pre-COVID-19, subsidized lunch programs provided another source of consistent food for students in Seattle, with 32.7\% of students in Seattle Public Schools in 2017 eligible for free and reduced lunch (Seattle Public Schools, 2019). Black, Indigenous, and People of Color (BIPOC) students and families are disproportionately represented in free and reduced lunch. In October 2018, 83\% of Black students and $59 \%$ of Hispanic students in Seattle Public Schools were enrolled in free and reduced lunch, as opposed to only $8 \%$ of white students (Seattle Public Schools, 2019). Seattle Public Schools closed their buildings to students due to COVID-19 on March 12 for the remainder of the 2019-2020 school year. Students began the 20202021 school year remotely until initiating a rolling, partial reopening beginning in March 2021, yet students still did not eat lunch on campus (Seattle Public Schools, 2021a). As a result, the district responded with a commitment to maintain distribution of free and reduced meals, as well as include all Seattle Public School students, parents, and guardians, regardless of income. The district distributed free sack breakfasts and lunches on weekdays at established sites and along bus routes around the city through the end of the school year (Seattle Public Schools, 2020b). Seattle Public Schools partners with the Backpack Brigade and Food for Schools to provide weekend food support for all qualified students. Over the summer of 2020, students also received emergency meal support, and families whose children qualified for free and reduced lunch received extra food benefits through Pandemic Electronic Benefits Transfer (PEBT) (Seattle Public Schools, 2020b). Eligible students were able to access free meals in the summer of 2021 (Seattle Human Services, 2021a), and all Seattle Public School students, regardless of income, will be provided with free school meals in the 2021-2022 school year (Seattle Public Schools, 2021b).

\section{Food Banks and COVID-19}

Food assistance organizations are an essential part of Seattle's food system in non-emergency times, in response to a $9.5 \%$ food insecurity rate in King
County in 2018 (Feeding America, 2020a). The food safety net in Seattle consists of food banks and food pantries, federal assistance programs, school meal programs, home delivery, and any other nonprofits aimed at directly providing food. Even before COVID-19, food banks had experienced increased demand, particularly for older adults and people experiencing homelessness (Bolt et al., 2019). In a report by the city of Seattle, $60 \%$ of food banks surveyed said that they had had a rise in food bank demand over the last year, and among these respondents, 39\% reported that their funding had remained the same (Bolt et al., 2019). Sixty-five percent of food banks surveyed had to reduce their variety of food and $41 \%$ had to reduce volume of food (Bolt et al., 2019).

During the coronavirus pandemic, food banks are tasked with supporting food security while adapting to the barriers presented by COVID-19 and the increased demand for food. Feeding America has reported that two of five people seeking food during the pandemic are first-time visitors to its network of food banks (Morello, 2020). An estimated additional 17.1 million people will need food support throughout the pandemic, which equates to about a $46 \%$ increase over prepandemic times (Feeding America, 2020b).

As the markets for restaurants and catering shut down, distributors struggled to keep up with repackaging and shifting to retail, resulting in food waste (Larochelle, 2020; Yaffe-Bellany \& Corkery, 2020). Meanwhile, panic-buying earlier in the pandemic stripped grocery stores of staples, resulting in less donated inventory for food banks. These shocks in the food supply chain resulted in increased food waste from producers while grocery stores and food banks have empty shelves (Conlin et al., 2020). In response, many food banks are building new partnerships with farms and businesses to supplement their produce and food supply (Morello, 2020). For example, the USDA Farm to Family Food Box Program partnered with food distributors of all sizes to purchase crops that would have otherwise been sold to restaurants or bulk providers, preventing food waste. Distributors then packaged products into family-sized boxes and distributed them to food banks and nonprofits (USDA Agricultural Marketing, 2020). When the 
program was up and running, lawmakers questioned the efficacy of the program and the USDA's choice of distributors, many of which have little experience distributing produce (Mccrimmon, 2020).

Food banks also rely heavily on volunteer labor but are facing shortages of volunteers, a large proportion of whom are older adults who are at higher risk for COVID-19 complications (Kulish, 2020). During these challenging times, food banks are also changing their operations to minimize the spread of COVID-19, including switching to prepackaged boxes and implementing social distancing guidelines (Morello, 2020).

Food Bank Communication During COVID-19 During these volatile times, as food banks' operations and supply chains shift, reliable communication between food banks and clients is essential. Governments and other emergency organizations have included social media as part of their comprehensive communication campaigns for emergencies to varying degrees (Scott \& Errett, 2018). Many food banks use their websites and social media to communicate with their clients on a regular basis. Yet, it remains unknown if and how food banks have utilized web and social media platforms to communicate dynamic food security-relevant information to a growing clientele amid a widespread emergency.

In response, we conducted a cross-sectional content analysis of website and social media posts from Seattle food banks early in the COVID-19 emergency to assess the presence of information on the three core components of food security to clients: food availability, acceptability, and accessibility. Through this exploratory, descriptive study, we aim to identify the types and frequency of information food banks are communicating to clients and opportunities for food banks and other emergency food organizations to enhance their emergency communication.

\section{Methods}

We conducted a content analysis of web and social media communications made by Seattle food banks in April and May 2020. We chose these months because they cover almost all of Governor Inslee's stay-at-home order period, which expired on May 31, 2020 (Figure 1).

All food banks included were members of the Seattle Food Committee, a coalition of food banks in Seattle (Seattle Food Committee, n.d.). After excluding one due to its permanent closure, 26 food banks were included in our study. Each food bank's website and social media pages (Facebook, Instagram, and Twitter) were reviewed, as available. We elected to only capture data from the social media pages of stand-alone food banks to ensure that all posts we captured related to emergency food.

\section{Websites}

Twenty-five of the 26 food banks had websites as of May 11, 2020. For organizations that function primarily as food banks $(n=11)$, all posts related to COVID-19 were captured via screenshot (see Appendix B for the website protocol). If the food bank was part of a larger organization such as a church or other nonprofit, only posts that related to the food bank or emergency food were captured via screenshot $(n=14)$. We conducted two crosssectional data captures on April 10 and May 11, 2020 .

\section{Social Media}

Eleven of the 26 organizations had social media pages dedicated to their food bank. Of these social media pages, all posts on Facebook, Instagram, and Twitter from April and May 2020 were captured via screenshot.

We developed a codebook a priori to assess whether communications contained information related to food availability, accessibility, and acceptability in the context of COVID-19, as well as other descriptive information, such as changes to hours and populations served (see the codebook in Appendix A).

Two coders (AI and AK) independently applied the codebook using NVivo software (QSR International). Only text content was coded. The application of the codes by individual coder was compared and discrepancies were adjudicated through a consensus-building discussion (Hill et al., 1997, 2005). A Microsoft Excel database was created to record the presence or absence of content 
on availability, accessibility, and acceptability in each post, stratified by date, organization, and platform (i.e., website, Twitter, Instagram, or Facebook). Summary statistics were calculated to assess the proportion of organizations and proportion of posts by organization that contained relevant information by platform.

\section{Results}

\section{Operational Changes Due to COVID-19}

In addition to communications on food availability, accessibility, and acceptability, we coded website and social media posts for descriptive information. Table 2 reports the percentage of food banks that communicated operational impacts due to the pandemic on either their websites or social media. The majority of food banks in our sample communicated changes to how clients interact with the food bank (e.g., walk-up windows, social distancing in lines) and the presentation of food to clients (e.g., prepackaged boxes to limit exposure). About half of the food banks reported a change to their hours of operation due to COVID-19, and 36\% communicated a change in location.

\section{By Food Bank-Websites}

Of the 25 food banks with websites, the majority

Table 2. Proportion of Seattle Food Banks ( $N=25$ ) that Communicated Any Operational Changes Due to COVID-19 in April and May 2020

\begin{tabular}{lc}
\hline Variable & \% of Food Banks $(n)$ \\
\hline Change to Hours & $44 \%(11)$ \\
\hline Change of Location & $36 \%(9)$ \\
\hline Client Interaction with Food Bank & $68 \%(17)$ \\
\hline Presentation of Food to Client & $64 \%(16)$ \\
\hline
\end{tabular}

communicated at least once about food availability and accessibility on their website. Far fewer food banks $(36 \%)$ had any communication about food acceptability in their web posts (Table 3 ).

\section{By Food Bank-Social Media}

Of the 11 food banks in our sample with standalone social media pages, all had Facebook pages, nine had Instagram accounts, and 10 had Twitter accounts. Most of these food banks discussed availability and accessibility at least once on one of their social media pages. Ten of 11 food banks (91\%) communicated at least once about food availability in the context of COVID-19, and eight of $11(73 \%)$ communicated about accessibility. In April and May, only two foodbanks (18\%) discussed food acceptability (Table 4).

\section{Website Posts}

We identified and captured 100 unique web posts on April 10 and May 11. Across all food banks, 'food accessibility' was the most common theme communicated in COVID-19-related website posts in April and May (Table 5). Forty-eight percent of COVID-19-related website posts across all food banks discussed food accessibility. Ninetyeight percent of posts that communicated accessibility related to 'physical solutions' to food access

Table 3. Proportion of Seattle Food Banks $(N=25)$ that Had Any Website Communication on Themes Related to Food Availability, Accessibility, and Acceptability in April and May 2020

\begin{tabular}{lc}
\hline Component of food security & \% of Food Banks $(\boldsymbol{n})$ \\
\hline Availability & $60 \%(15)$ \\
\hline Accessibility & $64 \%(16)$ \\
\hline Acceptability & $36 \%(9)$ \\
\hline
\end{tabular}

Table 4. Proportion of Seattle Food Banks that Had Any Social Media Communication on Themes Related to Food Availability, Accessibility, and Acceptability in April and May 2020

\begin{tabular}{lccc}
\hline $\begin{array}{l}\text { Component of food } \\
\text { security }\end{array}$ & $\begin{array}{c}\text { Facebook } \\
\text { Food banks with } \\
\text { Facebook }(n=11)\end{array}$ & $\begin{array}{c}\text { Instagram } \\
\text { Food banks with } \\
\text { Instagram }(n=9)\end{array}$ & $\begin{array}{c}\text { Twitter } \\
\text { Food Banks with } \\
\text { Twitter }(n=10)\end{array}$ \\
\hline Availability & $91 \%(10)$ & $67 \%(6)$ & $50 \%(5)$ \\
\hline Accessibility & $73 \%(8)$ & $33 \%(3)$ & $30 \%(3)$ \\
\hline Acceptability & $18 \%(2)$ & $0 \%(0)$ & $0 \%(0)$ \\
\hline
\end{tabular}


Table 5. Proportion of Seattle Food Bank Website Posts that Communicated Themes Related to Food Availability, Accessibility, and Acceptability in April and May, 2020

\begin{tabular}{|c|c|c|}
\hline $\begin{array}{l}\text { Component of Food } \\
\text { Security }\end{array}$ & $\begin{array}{l}\% \text { and }(n) \text { of Posts } \\
\qquad(N=100)\end{array}$ & Examples \\
\hline \multirow[t]{2}{*}{ Availability } & $32 \%(32)$ & $\begin{array}{l}\text { "We have increased our client numbers...however with the supply chains being } \\
\text { unstable, we are in need of donated food items to provide to our clients." (Food } \\
\text { Bank } 6 \text {, April) }\end{array}$ \\
\hline & & $\begin{array}{l}\text { "One of the unforeseen consequences of the coronavirus has been a reduction in } \\
\text { donations of fresh groceries and non-perishable food to our food banks." (Food } \\
\text { Bank } 7 \text {, May) }\end{array}$ \\
\hline \multirow[t]{2}{*}{ Accessibility } & $48 \%(48)$ & $\begin{array}{l}\text { "We are temporarily expanding our home delivery program. Food will be dropped off } \\
\text { at your front door." (Food Bank } 2 \text {, April) }\end{array}$ \\
\hline & & $\begin{array}{l}\text { "We are now distributing boxes and bags of food through our truck docking station } \\
\text { right near our front door. This procedure enables us to get the food they need and } \\
\text { strengthens social distancing to make certain everyone is safe!" (Food Bank 20, } \\
\text { May) }\end{array}$ \\
\hline \multirow[t]{2}{*}{ Acceptability } & $17 \%(17)$ & $\begin{array}{l}\text { "We cannot guarantee certain types of food each week. We will do our best to } \\
\text { accommodate allergies noted in your application." (Food Bank 18, April) }\end{array}$ \\
\hline & & $\begin{array}{l}\text { "At check-in we will hand you a sheet to fill out your specific food preferences. Note } \\
\text { any dietary restrictions and allergies that you have." (Food Bank 22, May) }\end{array}$ \\
\hline
\end{tabular}

(e.g., home meal delivery, giving out free face masks to shoppers), as opposed to 'economic accessibility' (e.g., transportation vouchers) (0\%) or general accessibility $(2 \%)$.

'Food availability' was the next most common theme and was present in $32 \%$ of website posts in April and May. Posts that discussed COVID-19related impacts to food sources and barriers to maintaining their supply of food were most prevalent among posts discussing availability. Of the 32 posts related to food availability, $53 \%$ discussed COVID-19 impacts to 'food sources,' and 56\% discussed 'barriers.'

'Food acceptability' was the least common theme found among website posts. Less than a quarter of website posts discussed food acceptability (17\%). Forty-seven percent of posts on acceptability discussed nutritional acceptability as opposed to medical $(24 \%)$ and cultural (6\%) acceptability. This included communication on the availability of certain food items, disclaimers to clients about lack of choice, and efforts to accommodate clients' food preferences. In Table 5 we provide some examples to illustrate food banks' communication on these themes.

\section{Social Media Posts}

In our sample, Facebook posts composed the majority of all social media posts, followed by Twitter and then Instagram. 'Food availability' was the most common theme across all social media platforms and was discussed in $21 \%$ of social media posts. Accessibility was the next most prevalent theme, with $11 \%$ of social media posts.

Table 6. Proportion of Seattle Food Bank Social Media Posts that Communicated Themes Related to Food Availability, Accessibility, and Acceptability in April and May, 2020, by Social Media Channel

\begin{tabular}{lcccc}
\hline & $\begin{array}{c}\text { Facebook } \\
\text { Posts }(\boldsymbol{n = 2 5 0 )}\end{array}$ & $\begin{array}{c}\text { Instagram } \\
\text { Posts }(\boldsymbol{n}=\mathbf{9 5})\end{array}$ & $\begin{array}{c}\text { Twitter } \\
\text { Posts }(\boldsymbol{n}=\mathbf{1 4 9})\end{array}$ & $\begin{array}{c}\text { Overall } \\
\text { Posts }(\boldsymbol{n}=\mathbf{4 9 4})\end{array}$ \\
\hline Availability & $22 \%(54)$ & $23 \%(22)$ & $20 \% 0(30)$ & $21 \%(106)$ \\
\hline Accessibility & $11 \%(27)$ & $13 \%(12)$ & $9 \%(13)$ & $11 \%(52)$ \\
\hline Acceptability & $1 \%(3)$ & $0 \%(0)$ & $0 \%(0)$ & $1 \%(3)$ \\
\hline
\end{tabular}




\section{Table 7. Examples from Social Media Posts}

\begin{tabular}{|c|c|}
\hline $\begin{array}{l}\text { Component of } \\
\text { food security }\end{array}$ & Example \\
\hline & $\begin{array}{l}\text { "We have never seen food move this fast through the food bank. Learn more about what we need } \\
\text { right now to keep out community fed through COVID." (Food Bank 18, April) }\end{array}$ \\
\hline Availability & $\begin{array}{l}\text { "A lot of canned and ready-to-eat food has been harder to find through our normal bulk ordering } \\
\text { sources. We're asking for in-kind food donations to add variety to our Emergency 'No-Cook' Bags." } \\
\text { (Food Bank 7, April) }\end{array}$ \\
\hline \multirow[b]{2}{*}{ Accessibility } & $\begin{array}{l}\text { "We have suspended our registration process and are simply giving groceries (including diapers and } \\
\text { formula) to our neighbors." (Food Bank 11, April) }\end{array}$ \\
\hline & $\begin{array}{l}\text { "We are sending a letter in NINE languages to about } 100 \text { of our seniors today...letting them know we } \\
\text { could deliver food to them if needed." (Food Bank 7, April) }\end{array}$ \\
\hline Acceptability & $\begin{array}{l}\text { "This helps us increase the number of individuals and families receiving home delivery, as well as } \\
\text { provide culturally appropriate food to meet the needs of our diverse community." (Food Bank } 2 \text {, May) }\end{array}$ \\
\hline
\end{tabular}

The theme of acceptability was largely absent among overall social media posts, being mentioned in just 3 of $250(\sim 1 \%)$ Facebook posts in April and May. In Tables 6 and 7, we provide proportions and some examples to illustrate Seattle food banks' communication on these themes.

\section{Discussion}

Our analysis of food bank websites and social media posts during COVID-19 serves both as a gauge for the extent to which food banks are communicating COVID-19 information to the community, and their experiences addressing the three core components of food security during the COVID-19 pandemic. Food banks in our sample emphasized mainly availability and accessibility of food during COVID-19, while acceptability was less prevalent in website and social media posts.

Physical and economic access to available, appropriate food is uniquely threatened by COVID-19. The loss of regular food avenues like group meals for older adults and school lunches for youth, coupled with staggering unemployment rates in the U.S., pose challenges for already vulnerable populations to maintain their food supply (Kochhar, 2020; Siddiqi et al., 2020). Because food banks already supply food at little to no cost to community members, food affordability was not as relevant to our study as physical access to the food bank. Our study indicates that Seattle food banks are taking a variety of steps to ensure that their clients have safe access to emergency food by limiting COVID-19 exposure. Examples of these efforts include increasing home deliveries, changing procedures for receiving food, and switching to prepackaged to-go food boxes. One food bank (Food Bank 7) even sent letters to regular foodbank visitors that they had not seen recently, translated to their native language, encouraging them to sign up for home delivery.

Website and social media posts also indicated that food banks' availability of food was affected by COVID-19. Some communicated about the speed at which food moved through the food bank due to an increase in visitors, which together with shocks in supply chains was making it difficult to acquire certain food items. Many food banks solicited donations of specific items or cash or thanked new partnerships like local businesses or restaurants for donating. Posts also communicated that food banks experienced barriers to receiving supplies through their regular avenues, such as grocery stores or individuals' donations of fresh produce.

In our sample, food acceptability was less discussed in the online communications of food banks. Over April and May, only two food banks discussed food acceptability on social media. Acceptability was also the least prevalent theme in both social media and website posts in April and May. Where the theme was present, some food banks stated that they may need to sacrifice food acceptability in order to implement safer policies or due to supply issues. One food bank communicated that they would provide fresh produce and 
proteins as availability allowed (Food Bank 7). The switch from a grocery store model to prepackaged food boxes by many food banks limits person-toperson exposure but reduces the clients' autonomy to choose their food (Sheil, 2020).

We cannot conclude how food banks' communication to clients reflects their actual operations. Nevertheless, we propose that emphasizing acceptability in communications to clients is essential to drawing more clients to the food bank. As some food banks in our sample communicated, COVID19 has reduced their capacity to provide as diverse a range of food as they did before the pandemic. Without information telling current and prospective clients differently, people with allergies or other specific diets may be averse to visiting a food bank, with potential cascading limitations in the types of clients served.

Further, our findings may help food banks understand the broader themes they are communicating to clients during emergencies and inform more intentional communications campaigns. Individual food banks may use this framework to evaluate their own communications during COVID-19. We recommend that food assistance organizations incorporate communication as part of their emergency response and business continuity plans based on the three dimensions of food security.

More research is needed on the broad implications of emergency food acceptability, such as post-disaster health outcomes, likeliness to visit a food bank, and mental health. Prior research and news media anecdotes have demonstrated that food acceptability has a direct bearing on people's ability to utilize emergency food resources (ColónRamos et al., 2019; Karoub, 2014). In the context of COVID-19, food acceptability issues have already made national news. For example, on social media, students at New York University and other schools shared photos of unappetizing meals and meals with foods that did not meet their dietary requirements (e.g., a meal of primarily bread for a student with a gluten allergy) that they were provided in their dorm rooms while isolating (Rosa, 2020). Communities may be more likely to access emergency food services if the food is culturally, nutritionally, and medically appropriate. To ensure that emergency food can be equitably distributed and enjoyed by diverse populations, acceptability must become a priority in emergency food planning.

\section{Study Limitations}

Our study was limited by a constrained geographic sampling frame and small sample size. By capturing website posts on two distinct days in April and May, we may have missed communications that food banks had released in the interim and removed by our next data capture. We purposively coupled our assessment of more static web communications with more dynamic and regularly updated social media posts to capture ongoing and real-time communication. Notably, we only included the social media pages for stand-alone food banks, which excluded data from food banks that are part of larger organizations. These organizations may have systematically different approaches to communication, for example, by having dedicated communication staff in-house.

Our study revolved around the commonly accepted three components of food security: availability, accessibility, and acceptability. While most conceptualizations of food security include some form of these three components, definitions of food security vary. For example, in a report from the Seattle city council, the authors included availability, accessibility, affordability, accommodation, and acceptability as their five components for healthy food access (Bolt et al., 2019).

Finally, social media and website posts do not give the full extent of how food banks are attempting to provide food. We only analyzed the information food banks communicated to clients on their online platforms, not the multitude of actions they completed behind the scenes to feed their communities throughout COVID-19. To fully understand the challenge of maintaining the three core components of food security during an emergency, food banks and clients should be surveyed or interviewed to capture their firsthand experiences. We also do not know if clients received this information or if it had any bearing on their behavior or resultant food security. Future research is needed on the reach and efficacy of disaster communication from emergency food organizations. 


\section{Conclusions}

Our study sought to assess if and how Seattle food banks utilized web and social media platforms to communicate information on food availability, accessibility, and acceptability during the initial response to COVID-19. Our findings show that food banks in Seattle used these platforms to communicate the most about food availability and accessibility, while food acceptability was far less commonly addressed. It is imperative for food acceptability to be included in emergency food planning and communication in the future to ensure that nutritional, medical, and cultural preferences are met. COVID-19 is an ongoing and evolving emergency that requires an iterative approach to learning and action. Food banks may wish to periodically assess the main themes of their online communications, as well as the reach of their different platforms during the COVID-19 pandemic, as strategies to facilitate community food security. Our study may help food banks understand the types of information they are communicating to clients during emergencies and inform improvements to holistic, client-centered emergency communications planning and implementation that addresses the three dimensions of food security.

\section{References}

Bauer, L. (2020, May 6). The COVID-19 crisis has already left too many children hungry in America. Brookings. https://www.brookings.edu/blog/up-front/2020/05/06/the-covid-19-crisis-has-already-left-too-many-childrenhungry-in-america/

Bolt, K., Carter, L., Casey, D., Chan, N. L., Chen, R., Jones-Smith, J. C., Knox, M., Oddo, V. M., Podrabsky, M., Saelens, B. E., Schachter, A., Ta, M., Pinero Walkinshaw, L., \& Yang, A. (2019). Healthy food availability \& food bank network report. https://www.seattle.gov/Documents/Departments/CityAuditor/auditreports/030519\%20Corrected $\% 20 \mathrm{Healthy} \%$ 20Food $\% 20$ Availability $\% 20$ Food $\% 20$ Bank $\% 20$ Network $\% 20$ Report FINAL.pdf

Chodur, G. M., Zhao, X., Biehl, E., Mitrani-Reiser, J., \& Neff, R. (2018). Assessing food system vulnerabilities: A fault tree modeling approach. BMC Public Health, 18, Article 817. https://doi.org/10.1186/s12889-018-5563-x

Colón-Ramos, U., Roess, A. A., Robien, K., Marghella, P. D., Waldman, R. J., \& Merrigan, K. A. (2019). Foods distributed during federal disaster relief response in Puerto Rico after Hurricane María did not fully meet federal nutrition recommendations. Journal of the Academy of Nutrition and Dietetics, 119(11), 1903-1915. https://doi.org/10.1016/j.jand.2019.03.015

Conlin, M., Baertlein, L., \& Walljasper, C. (2020, April 24). U.S. food banks run short on staples as hunger soars. Reuters. https://www.reuters.com/article/us-health-coronavirus-foodbanks-insight-idUSKCN2261AY

Drewnowski, A., Otten, J. J., Lewis, L. R., Collier, S. M., Sivaramakrishnan, B., Rose, C. M., Ismach, A., Nguyen, E., \& Buszkiewicz, J. (2020). Economic security and food access in Washington State during the COVID-19 pandemic [Research brief]. WAFOOD. https://nutr.uw.edu/wp-content/uploads/2020/09/WAFOOD intro brief 20200917.pdf

Food and Agriculture Organization of the United Nations [FAO]. (1996). Report of the World Food Summit. http://www.fao.org/3/w3548e/w3548e00.htm

FAO. (2006). Food security [Policy brief, issue 2]. https://www.fao.org/fileadmin/templates/faoitaly/documents/pdf/pdf Food Security Cocept Note.pdf

Feeding America. (2020a). Map the meal gap. https://map.feedingamerica.org/

Feeding America. (2020b, May 20). Feeding America Study projects local food insecurity rates amid pandemic could reach up to 1 in 3 adults and 1 in 2 children [Press release]. https://www.feedingamerica.org/about-us/press-room/feeding-americastudy-projects-local-food-insecurity-rates-amid-pandemic-could

Gundersen, C., \& Ziliak, J. P. (2015). Food insecurity and health outcomes. Health Affairs, 34(11), 1830-1839. https://doi.org/10.1377/hlthaff.2015.0645

Hill, C. E., Knox, S., Thompson, B. J., Williams, E. N., Hess, S. A., \& Ladany, N. (2005). Consensual qualitative research: An update. Journal of Counseling Psychology, 52(2), 196. https://doi.org/10.1037/0022-0167.52.2.196 
Hill, C. E., Thompson, B. J., \& Williams, E. N. (1997). A guide to conducting consensual qualitative research. The Counseling Psychologist, 25(4), 517-572. https://doi.org/10.1177/0011000097254001

Institute for Health Metrics and Evaluation [IHME]. (2020, September 11). Covid-19 projections. https://covid19.healthdata.org/united-states-of-america/washington

Johansson, R. (2020, May 28). Another look at availability and prices of food amid the COVID-19 pandemic. Retrieved September 18, 2020, from U.S. Department of Agriculture website: https:/www.usda.gov/media/blog/2020/05/28/anotherlook-availability-and-prices-food-amid-covid-19-pandemic

Karoub, J. (2014, April 26). Sandy reveals need for federal kosher, halal supplies. Oneida Daily Dispatch. https://www.oneidadispatch.com/news/sandy-reveals-need-for-federal-kosher-halal-supplies/article f0413983820a-5857-a820-0dd9e0a2860e.html

KING 5 Staff. (2020, June 1). Washington's stay-at-home order ends as more counties gradually reopen. KING5. https://www.king5.com/article/news/health/coronavirus/washington-state-new-phases-guidelines-forreopening/281-9ca55fc2-ce05-47a7-af4a-ebffd0c79094

King County. (2020a, June 5). King County to immediately allow limited openings of businesses, maintain public health vigilance. https://www.kingcounty.gov/elected/executive/constantine/news/release/2020/June/05-phase-covid.aspx

King County. (2020b, July 31). Current COVID-19 guidance in King County. Retrieved August 6, 2020, from https://kingcounty.gov/elected/executive/constantine/covid-response/safe-start.aspx

Kinsey, E. W., Hecht, A. A., Dunn, C. G., Levi, R., Read, M. A., Smith, C., Niesen, P., Seligman, H. K., \& Hager, E. R. (2020). School closures during COVID-19: Opportunities for innovation in meal service. American Journal of Public Health, 110(11), 1635-1643. https://doi.org/10.2105/AJPH.2020.305875

Kochhar, R. (2020, June 11). Unemployment rose higher in three months of COVID-19 than it did in two years of the Great Recession. Pew Research Center. https://www.pewresearch.org/fact-tank/2020/06/11/unemployment-rose-higher-in-threemonths-of-covid-19-than-it-did-in-two-years-of-the-great-recession/

Kulish, N. (2020, April 8). 'Never seen anything like it': Cars line up for miles at food banks. The New York Times. https://www.nytimes.com/2020/04/08/business/economy/coronavirus-food-banks.html

Larochelle, C. (2020, April 29). Ravi Anupindi: COVID-19 shocks food supply chain, spurs creativity and search for resiliency. University of Michigan News. https://news.umich.edu/covid-19-shocks-food-supply-chain-spurs-creativity-and-search-for-resiliency/

Mccrimmon, R. (2020, May 27). Lawmakers zero in on USDA food box contract. Politico. https://www.politico.com/newsletters/morning-agriculture/2020/05/27/lawmakers-zero-in-on-usda-food-boxcontract-787908

McNerthney, C. (2020, April 3). Coronavirus in Washington state: A timeline of the outbreak through March 2020. Retrieved August 6, 2020, from Kiro 7 website: https://www.kiro7.com/news/local/coronavirus-washington-state-timelineoutbreak/IM65JK66N5BYTIAPZ3FUZSKMUE/

Morello, P. (2020, May 4). COVID means a new normal for food banks. Retrieved June 18, 2020, from Feeding America website: https://www.feedingamerica.org/hunger-blog/covid-19-means-new-normal

Naja, F., \& Hamadeh, R. (2020). Nutrition amid the COVID-19 pandemic: A multi-level framework for action. European Journal of Clinical Nutrition, 74, 1117-1121. https://doi.org/10.1038/s41430-020-0634-3

Niles, M. T., Bertmann, F., Belarmino, E. H., Wentworth, T., Biehl, E., \& Neff, R. (2020). The early food insecurity impacts of COVID-19. Nutrients, 12(7), Article 2096. https://doi.org/10.3390/nu12072096

Niles, M. T., Bertmann, F., Morgan, E. H., Wentworth, T., \& Biehl, E. (2020). Food access and security during coronavirus: A Vermont study. College of Agriculture and Life Sciences Faculty Publications, 21. https:/ / scholarworks.uvm.edu/cgi/viewcontent.coi?article $=1019 \&$ context $=$ calsfac

Rosa, A. (2020, August 22). Crummy college quarantine food goes viral: A lemon as a side dish? The New York Times. https://www.nytimes.com/2020/08/22/nyregion/coronavirus-tiktok-college-quarantine-food.html

Scott, K. K., \& Errett, N. A. (2018). Content, accessibility, and dissemination of disaster information via social media during the 2016 Louisiana floods. Journal of Public Health Management and Practice, 24(4), 370-379. https://doi.org/10.1097/PHH.0000000000000708 
Seattle Food Committee. (n.d.). About. http://www.seattlefoodcommittee.org/about-the-sfc/

Seattle Human Services. (2021). Children and Youth Summer Food Service Program. https://www.seattle.gov/humanservices/services-and-programs/preparing-youth-for-success/summer-foodservice-program

Seattle Public Schools. (2019). Demographics data tables. https://www.seattleschools.org/departments/dots/datareporting-reporting-and-data-analysis/data-profile-district-summary-2/data-profile-demographics/demographicsdata-tables/

Seattle Public Schools. (2020a, September 8). Student meals bus delivery [No longer online].

Seattle Public Schools. (2020b). Student meals [No longer online].

Seattle Public Schools (2021a) Return to in-person [No longer online].

Seattle Public Schools (2021b). Culinary Services. https://www.seattleschools.org/departments/culinary-services/

Senator Kirsten Gillibrand. (2016, February 29). Senator Gillibrand urges U.S. Department of Agriculture to provide update on purchase of kosher and halal food for food banks [Press release]. https://www.gillibrand.senate.gov/news/press/release/senator-gillibrand-urges-us-department-of-agriculture-toprovide-update-on-purchase-of-kosher-and-halal-food-for-food-banks

Sheil, H. (2020, May 26). Local food banks face growing need, changing operations amid coronavirus impact. Westside Seattle. https://www.westsideseattle.com/ballard-news-tribune/2020/05/26/local-food-banks-face-growing-needchanging-operations-amid

Siddiqi, S. M., Cantor, J., Dubowitz, T., Richardson, A., Stapleton, P. A., \& Katz, Y. (2020, March 31). Food access: Challenges and solutions brought on by COVID-19. RAND Corporation. https://www.rand.org/blog/2020/03/foodaccess-challenges-and-solutions-brought-on-by.html

USDA Agricultural Marketing Service. (2020, September 16). USDA Farmers to Families Food Box. https://www.ams.usda.gov/selling-food-to-usda/farmers-to-families-food-box

Wolfson, J. A., \& Leung, C. W. (2020a). Food insecurity and COVID-19: Disparities in early effects for US adults. Nutrients, 12(1648). https://doi.org/10.3390/nu12061648

Wolfson, J. A., \& Leung, C. W. (2020b). Food insecurity during COVID-19: An acute crisis with long-term health implications. American Journal of Public Health, 110(12), 1763-1765. https://doi.org/10.2105/AJPH.2020.305953

Wolfson, J. A., Leung, C. W., \& Kullgren, J. T. (2020). Food as a critical social determinant of health among older adults during the coronavirus disease 2019 (COVID-19) Pandemic. JAMA Health Forum, 1(7), Article e200925. https://doi.org/10.1001/jamahealthforum.2020.0925

Yaffe-Bellany, D., \& Corkery, M. (2020, April 11). Dumped milk, smashed eggs, plowed vegetables: Food waste of the pandemic. The New York Times. https://www.nytimes.com/2020/04/11/business/coronavirus-destroying-food.html

Zeuli, K., \& Nijhuis, A. (2017). The resilience of America's urban food systems: Evidence from five cities. Initiative for a Competitive Inner City. 


\section{Appendix A. Definitions of Codes}

\begin{tabular}{|c|c|c|}
\hline Code & Definition & Example \\
\hline \multicolumn{3}{|l|}{ Basic Info } \\
\hline Changes to Hours & $\begin{array}{l}\text { COVID-19 related changes to hours of } \\
\text { distribution. }\end{array}$ & \\
\hline Change of Location & $\begin{array}{l}\text { COVID-19 related changes to location of } \\
\text { distribution. }\end{array}$ & $\begin{array}{l}\text { Home deliveries, new distribution sites, } \\
\text { operating out of parking lot }\end{array}$ \\
\hline $\begin{array}{l}\text { Guest Interaction with } \\
\text { Food Bank (NPI) }\end{array}$ & $\begin{array}{l}\text { Procedures for waiting in line, entering } \\
\text { facilities or retrieving food. }\end{array}$ & $\begin{array}{l}\text { Standing }>6 \text { feet apart in line, limiting quantity of } \\
\text { people entering food bank, no contact (food left } \\
\text { on doorstep) }\end{array}$ \\
\hline Food Presentation & Changes to how food is presented to clients. & Prepackaged boxes/bags \\
\hline Food Availability & \multicolumn{2}{|c|}{$\begin{array}{l}\text { Discusses the current and/or expected supply of food for redistributing to clients in the context of } \\
\text { COVID-19. }\end{array}$} \\
\hline AV: Food Sources & $\begin{array}{l}\text { Discusses COVID-19 impacts to where the } \\
\text { food bank obtains the food that they redistrib- } \\
\text { ute. Ex. Donations from businesses, individual } \\
\text { donations, governmental surplus. }\end{array}$ & $\begin{array}{l}\text { Reduction in donations from individuals, } \\
\text { businesses, cancelled food drives }\end{array}$ \\
\hline AV: Partnerships & $\begin{array}{l}\text { Discusses COVID-19 impacts to the food bank } \\
\text { and other partner nonprofit organizations, } \\
\text { private businesses, governmental bodies in } \\
\text { relation to food availability. }\end{array}$ & $\begin{array}{l}\text { Increased emergency food aid from the } \\
\text { government, reduction in grocery store supply, } \\
\text { support from other nonprofits and community } \\
\text { orgs like Northwest Harvest }\end{array}$ \\
\hline AV: Quantity & $\begin{array}{l}\text { Discusses COVID-19 impacts to the amount of } \\
\text { food available for the food bank and clients. }\end{array}$ & $\begin{array}{l}\text { Specific figure of amount distributed during } \\
\text { COVID-19, reduction or increase in supply }\end{array}$ \\
\hline AV: Barriers & $\begin{array}{l}\text { Discusses COVID-19 related challenges to } \\
\text { maintaining their supply of food. }\end{array}$ & $\begin{array}{l}\text { Reduction in donations, increased operation } \\
\text { costs associated with COVID affecting food } \\
\text { supply }\end{array}$ \\
\hline AV: Solutions & $\begin{array}{l}\text { Discusses solutions for maintaining their } \\
\text { supply of food in the context of COVID-19. }\end{array}$ & Limitations on weekly visits, online donations \\
\hline Food Accessibility & \multicolumn{2}{|c|}{$\begin{array}{l}\text { Discusses issues of clients' physical and economic access to the food that the organization } \\
\text { supplies in the context of COVID-19. }\end{array}$} \\
\hline ACC: Economic Solutions & $\begin{array}{l}\text { Discusses or presents immediate COVID-19 } \\
\text { related challenges, opportunities or resources } \\
\text { for clients to overcome economic barriers to } \\
\text { accessing their services. }\end{array}$ & Transportation vouchers, sliding scale meals \\
\hline ACC: Physical Solutions & $\begin{array}{l}\text { Discusses or presents challenges, opportu- } \\
\text { nities or resources for clients to overcome } \\
\text { physical barriers to accessing the food the } \\
\text { organization provides in the context of COVID- } \\
19 .\end{array}$ & $\begin{array}{l}\text { Ex. Mask provision, food delivery, organization's } \\
\text { effort to meet clients where they are }\end{array}$ \\
\hline Food Acceptability & \multicolumn{2}{|c|}{$\begin{array}{l}\text { Describes organization's experience or efforts providing nutritionally, culturally and medically } \\
\text { acceptable food to their clients in the context of COVID-19. }\end{array}$} \\
\hline ACCP: Cultural & $\begin{array}{l}\text { Describes organization's efforts or ability to } \\
\text { provide culturally appropriate food to their } \\
\text { clients in the context of COVID-19. }\end{array}$ & $\begin{array}{l}\text { Ex. Working with immigrant populations, } \\
\text { religious requirements, providing ingredients } \\
\text { specific to particular culture }\end{array}$ \\
\hline ACCP: Nutrition & $\begin{array}{l}\text { Describes organization's efforts or ability to } \\
\text { provide nutritious food to clients in the } \\
\text { context of COVID-19. }\end{array}$ & $\begin{array}{l}\text { Ex. Presence of fresh produce and protein, } \\
\text { variation of food provided }\end{array}$ \\
\hline
\end{tabular}


Journal of Agriculture, Food Systems, and Community Development ISSN: 2152-0801 online

https:/ / foodsystemsjournal.org

ACCP: Medical

Describes organization's efforts or ability to provide food for people with certain medical

Ex. Nut-free food, limited chewing ability, medior allergy requirements in the context of COVID-19.

Note: Updated 6/5/2020 "in the context of COVID-19" means either explicitly or implicitly mentions COVID-19. Ex. "during these hard times," "through this difficult period..." etc. 


\section{Appendix B. Protocol for Screenshotting Websites}

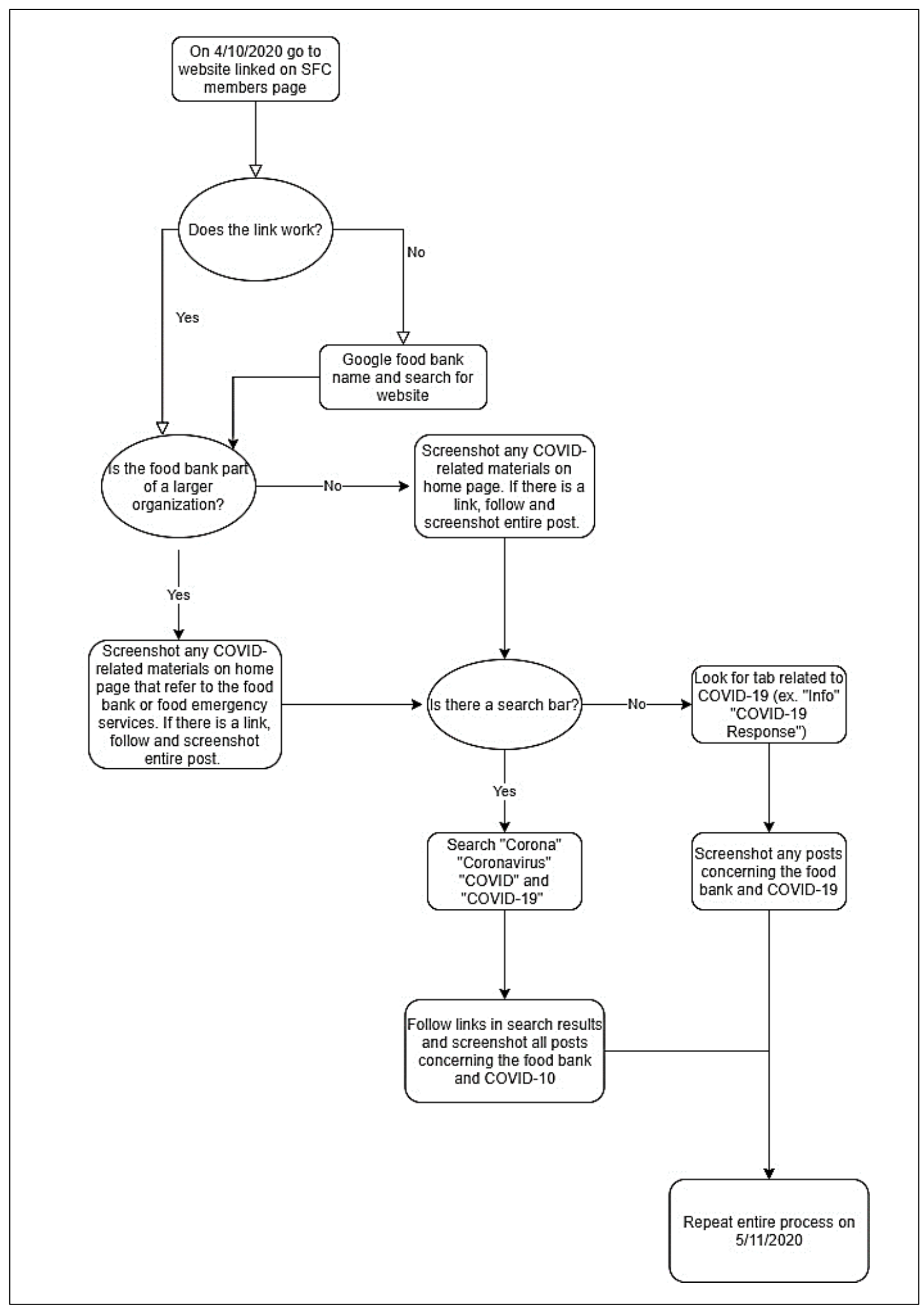

